\title{
Patterns of energy allocation to reproduction in three Amazonian fish species
}

\author{
Rodrigo N. dos Santos, Sidinéia Amadio and Efrem J. G. Ferreira
}

The study considered the influence of the hydrological cycle and gonadal development on the accumulation and use of energy in three fish species from an Amazonian flooded area. Fishes were sampled over a 24 hour period at monthly intervals between July 2004 and June 2005 using gillnets of different mesh sizes. Body cavity fat and gonadosomatic indices were determined, as well as energy content of gonads and muscles. Amongst the studied species, different means of energy allocation for reproduction were found: Acestrorhynchus falcirostris allocate energy from body cavity fat to its gonads; Pygocentrus nattereri uses mainly energy accumulated in the muscles for the process of gonadal maturation; and Hoplosternum littorale uses energy accumulated in their muscles and body cavity fat for reproductive processes. It is quite clear that the flood pulse regulates the gain and use of the energy reserves in fishes from the Amazonian floodplain.

O presente estudo considerou a influência do ciclo hidrológico e maturação gonadal no acúmulo e utilização da energia em três espécies de peixes, numa área de planície de inundação amazônica. As amostras foram obtidas mensalmente durante o período de julho de 2004 a junho de 2005, utilizando redes de emalhar com vários tamanhos de malhas, durante 24 horas. O índice de gordura cavitária, índice gonadossomático, e teor energético dos músculos e gônadas foram analisados. Dentre as espécies analisadas, foram detectados diferentes padrões de alocação de energia: Acestrorhynchus falcirostris aloca energia das reservas de gordura cavitária para as gônadas; Pygocentrus nattereri utiliza energia dos músculos para este fim e Hoplosternum littorale, além da gordura cavitária, utiliza também energia acumulada nos músculos para realização dos processos reprodutivos. Ficou evidente que o pulso de inundação exerce forte influência no acúmulo e utilização das reservas energéticas dos peixes da planície de inundação amazônica.

Key words: Amazon floodplain, Energy contents, Hydrological cycle, Reproductive biology.

\section{Introduction}

Patterns of energy allocation in fishes may change in accordance to the degree of sexual maturity of the individual, as timing of reproductive activity as well as maturation of the gonads require materials obtained from ingested food and energetic reserves deposited in various parts of the body (Tytler \& Calow, 1985). Amongst fish species, there are differences in the acquisition, accumulation and allocation of energy reserves, given variations in habitat, trophic category, nature and origin of food, as well as the reproductive strategy used by the species in question (Bennemann et al., 1996; Huntingford et al., 2001; Fiorin et al., 2007).

Studies that quantify the energy allocations of organisms have been frequently used to evaluate the magnitude of the allocation for reproduction (Huntingford et al., 2001; Jonsson \& Jonsson, 2005). Other studies have demonstrated that fish inhabiting areas with high seasonal variation in water level exhibit differences in the storage and allocation of energy reserves throughout the year (Carvalho, 1979; Junk, 1985; Finstad et al., 2003; Eggleton \& Schramm, 2004; Dourado \& Benedico-Cecílio, 2005).

Such variations in energy allocation can lead to modifications of the physiological state of the fish, which can be detected by measuring biological parameters such as the index of body cavity fat, gonadosomatic index, and the energetic density of somatic and reproductive tissues. These estimates are useful for investigating the life history strategies

Departamento de Biologia Aquática, Instituto Nacional de Pesquisas da Amazônia - INPA . Av. André Araújo, 2936, 69083-000 Manaus, AM, Brazil.santosrn@gmail.com 
of fish that inhabit areas with seasonal fluctuations (Chellappa et al., 1995; Encina \& Granado-Lorencio, 1997; Penczak et al., 1999; Hoffmayer et al., 2006).

In the Amazon, rivers exhibit a marked seasonal fluctuation in water level. This seasonality exerts a strong influence on the nutrient balance, trophic interactions, and energy cycle of aquatic environments, and consequently, over the aquatic and terrestrial fauna and flora (Junk et al., 1989). These periodical variations exert a strong selective pressure, with the entire biota developing physiologic, anatomic, and/or behavioural mechanisms to survive in these conditions (Val \& Almeida-Val, 1999). Main events on fishes' lives have been associated with the flood pulse (Goulding et al., 2003) and this constitutes an endless source of investigation on biological patterns, fact that stimulated this work.

The three fish species selected for this study are very common in the Amazonian floodplain (várzea) (Reis et al., 2003): Acestrorhynchus falcirostris (Cuvier, 1819) (Acestrorhynchidae, Characiformes), is a piscivorous species (Santos et al., 2008), which can reach up to $35 \mathrm{~cm}$ standard length (Ferreira et al., 1998) and occurs in the Amazon and Orinoco basin and Guiana rivers (Menezes, 2003); Hoplosternum littorale (Hancock, 1828) (Callichthyidae, Siluriformes) is a demersal fish reaching up to $20 \mathrm{~cm}$ standard length that uses its intestine as an air breathing organ (JucáChagas \& Boccardo, 2006), feeds mostly on microcrustaceans, rotifers, copepods, insect larvae and molluscs of the family Planorbidae (Santos et al., 2008), lives on the river bottom or adhering to substrates and is broadly distributed in South America (Reis, 2003). Pygocentrus nattereri Kner, 1858 (Characidae, Characiformes) is a piscivorous species (Santos et al., 2008), reaches up to $25 \mathrm{~cm}$ standard length and occurrs in the Amazon, Paraná-Paraguai and Essequibo basin, as well as in the Brazilian northeast rivers (Jégu, 2003).

There are no studies that quantify the allocation of energy for use in reproductive processes in seasonal environments in the Amazon basin. Thus, the hypothesis of this study considers there are differences in the strategy of energy allocation among fish species from the Amazon floodplain. The objective of this study was to identify the mode of energy used throughout a hydrological and reproductive cycle of three fish species in the flooded forest of the Amazon.

\section{Material and Methods}

\section{Study area}

This study was conducted in a flooded area of Central Amazon, Amazonas State, Brazil, at the confluence of the Amazonas and Negro Rivers, between the geographic

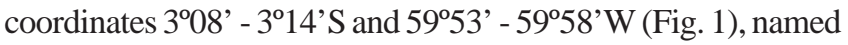
Catalão. This region corresponds to a low-lying land, which, depending upon the hydrological period, it floods to form a large lake continuous with the rivers or forms an isolated lake

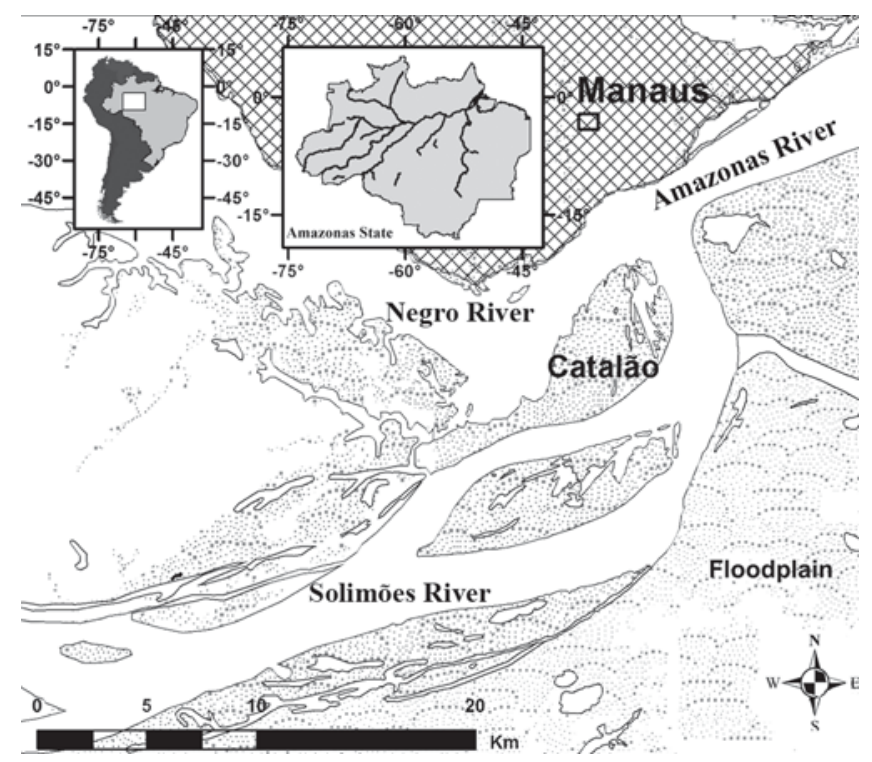

Fig. 1. Map of the Catalão region, located near Manaus, Amazonas State, showing the sampling site.

separated from the rivers.

The hydrological cycle at the study site was defined according to Bittencourt \& Amadio (2007), as consisting of four hydrological periods (Fig. 2). Rising: water entering the river system and water levels increasing, from mid December to beginning of March, between 20-26 m above sea level. High: water-level equal to or above $26 \mathrm{~m}$ above sea level, from beginning of March to end of July. Receding: water leaving the river system and water levels falling, from end of July to end of October, between 26-20 m above sea level. Low: waterlevel equal to or below $20 \mathrm{~m}$ above sea level, from end of October to mid December.

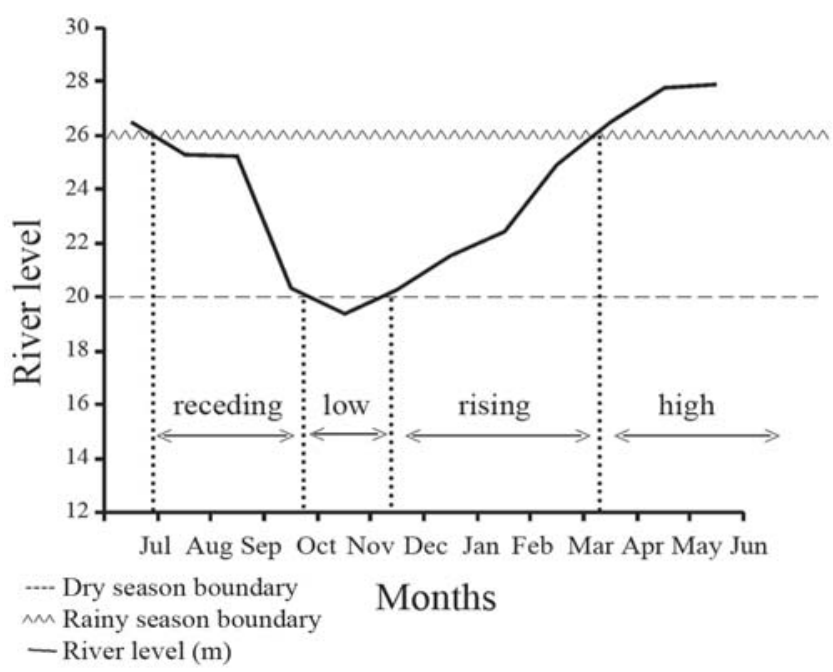

Fig. 2. Fluctuation of monthly average water level of the Negro River during the period of July 2004/ June 2005, showing the four phases of the hydrological cycle. Source: Bittencourt \& Amadio (2007). 


\section{Fish Sampling}

Fishes were sampled monthly from July 2004 to June 2005, using a set of 10 gillnets with mesh sizes ranging from 30 to $120 \mathrm{~mm}$ between opposite knots, measuring $10 \mathrm{x}$ 1.5-3.5 m. Nets were left in the water for $24 \mathrm{~h}$ and fish were removed every 6 hours. The few fish alive after being removed from the nets were anaesthetized with benzocaine $\left(1 \mathrm{~g} 10 \mathrm{l}^{-1}\right)$ and were all placed in plastic bags, stored in coolers with ice, and brought to the Laboratory at INPA, for measurements.

Standard length $\left(\mathrm{L}_{\mathrm{s}}-\mathrm{mm}\right)$, total weight $\left(\mathrm{W}_{\mathrm{t}}-\mathrm{g}\right)$, gonad weight $\left(\mathrm{W}_{\mathrm{g}}-\mathrm{g}\right)$ and body cavity fat weight $\left(\mathrm{W}_{\mathrm{f}}-\mathrm{g}\right)$ were recorded for each fish. Vouchers have been deposited in the Fish Collection of the Instituto Nacional de Pesquisas da Amazônia (A. falcirostris INPA 25652, H. littorale INPA 25614 and P. nattereri INPA 25615). There was no sampling of $P$. nattereri during the low-water period. Table 1 shows number of individuals, mean standard length and total weight of each species.

Gonad and body cavity fat development were calculated using the Gonadosomatic Index $\left(\mathrm{I}_{\mathrm{G}}=100 . \mathrm{W}_{\mathrm{g}} / \mathrm{W}_{\mathrm{t}}\right)$ and Body Cavity Fat Index $\left(\mathrm{I}_{\mathrm{F}}=100 . \mathrm{W}_{\mathrm{f}} / \mathrm{W}_{\mathrm{t}}\right)$ respectively. Only female specimens were used for this study as their gonadal stages were readily recognized. Development stages of gonads were determined based on the degree of vascularization, the percentage of the abdominal cavity occupied by ovaries, and presence, size and colour of oocytes (Vazzoler, 1996; Mazzoni \& Iglesias-Rios, 2002; Santos et al., 2005). The following classification was used: immature, maturing, ripe, and spawned/recovering. For the determination of energy content, a minimum of $2 \mathrm{~g}$ (wet weight) of muscle and gonad tissue was collected, to ensure a minimum $0.5 \mathrm{~g}$ dry weight sample. Samples were freeze-dried, ground to a fine homogeneous powder in a spherical mill and burned in a calorimetric bomb (Parr model 1261). To obtain the necessary sample weight for analysis in the macro-bomb, gonads in maturing and spawned/ recovering stages were pooled from individuals captured in the same period. For each species, an average of 10 individuals at each gonadal stage was considered; due to the low weight of the gonads of immature individuals, it was not possible to quantify their energy content.

\section{Statistical Analyses}

Variation in energy content of muscles and gonads, $\mathrm{I}_{G}$ and $\mathrm{I}_{\mathrm{F}}$, stage of gonadal development and hydrological periods of the year, within and between species, was analyzed by means of Analysis of Variance (ANOVA) followed by a Tukey's post hoc test for contrast between means (Zar, 1999).

Table 1. Number of individuals (N), standard length variation $\left(\mathrm{L}_{\mathrm{s}}\right)$ in $\mathrm{mm}$, mean standard length with standard deviations $\left(\mathrm{L}_{\mathrm{s}}\right)$ and mean total weight $\left(\mathrm{W}_{\mathrm{t}}\right)$ for each species.

\begin{tabular}{lcccc}
\hline \multicolumn{1}{c}{ Species } & $\mathrm{N}$ & Standard length $\left(\mathrm{L}_{\mathrm{s}}\right)$ & Mean values $\left(\mathrm{L}_{\mathrm{s}}\right)$ & $\mathrm{W}_{\mathrm{t}}(\mathrm{g})$ \\
\hline A. falcirostris & 152 & $111-298$ & $218.0 \pm 31.0$ & $119.4 \pm 55.7$ \\
H. littorale & 80 & $79-170$ & $133.9 \pm 15.6$ & $92.1 \pm 28.5$ \\
P. nattereri & 49 & $85-146$ & $111.5 \pm 16.4$ & $73.8 \pm 34.4$ \\
\hline
\end{tabular}

\section{Results}

\section{Variation in $I_{F}, I_{G}$ and caloric content of muscles and gonads throughout the hydrologic and reproductive cycle}

Acestrorhynchus falcirostris - there were significant differences in $I_{F}$ in some stages of gonadal development (Fig. 3a) and throughout the hydrologic cycle (Fig. 3d). Individuals with immature $(0.58 \% \pm 0.33)$ and ripe gonads $(0.66 \% \pm 0.13)$ exhibited a lower amount of body cavity fat, while the highest values were found in individuals with spawned/recovering $(1.99 \% \pm 0.12)$ and maturing gonads $(1.66 \% \pm 0.19)$ (ANOVA, $\mathrm{p}<0.01)$. Throughout the hydrologic cycle, the highest values of $\mathrm{I}_{\mathrm{F}}$ occurred during receding $(2.23 \% \pm 0.11)$ and low waters $(1.74 \% \pm 0.29)$ while the lowest values occurred during rising $(0.67 \% \pm 0.13)$ and high waters $(0.70 \% \pm 0.09)$. The receding and low water periods were significantly different from the rising and high water periods (ANOVA, $\mathrm{p}<0.01$ ).

In contrast to $\mathrm{I}_{\mathrm{F}}, \mathrm{I}_{\mathrm{G}}$ was highest in ripe individuals (5.65\% \pm 0.44 ), being significantly different (ANOVA, $p<0.01$ ) from other stages (Fig. $3 \mathrm{~b}$ ). When analyzed for the hydrologic cycle, $\mathrm{I}_{\mathrm{G}}$ exhibited an inverse pattern to $\mathrm{I}_{\mathrm{F}}$ again. The highest values of $\mathrm{I}_{\mathrm{G}}$ occurred during rising $(2.62 \% \pm 0.56)$ and high waters ( $3.80 \% \pm 0.53$; Fig. 3e), while the lowest values occurred during receding $(0.60 \% \pm 0.08)$ and low waters $(0.35 \% \pm 0.03)$ (ANOVA, $\mathrm{p}<0.01$ ). Most ripe individuals were sampled during the rising and high water periods whereas individuals with maturing and recovering gonads predominated during the receding and low water periods (Fig. 4a).

Individuals that had already started the reproductive cycle, that is, presented maturing ( $\left.20.1 \mathrm{~kJ} \mathrm{~g}^{-1} \mathrm{dw} \pm 0.5\right)$, ripe $\left(19.0 \mathrm{~kJ} \mathrm{~g} \mathrm{~g}^{-1} \mathrm{dw} \pm 1.5\right)$ and spawned/recovering $\left(18.70 \mathrm{~kJ} \mathrm{~g}^{-1} \mathrm{dw}\right.$ \pm 2.42 ) gonads did not exhibit significant differences in the energy content of their muscles. Nevertheless, immature individuals exhibited energy values $\left(16.60 \mathrm{~kJ} \mathrm{~g} \mathrm{~g}^{-1} \mathrm{dw} \pm 1.6\right)$ significantly lower than those individuals with maturing gonads (ANOVA, $\mathrm{p}<0.01$ ) (Fig. 3c). The energy content of ripe gonads (26.32 kJ g-1 dw \pm 2.64 ) was significantly higher (ANOVA, $\mathrm{p}<0.01$ ) from those maturing $\left(23.21 \mathrm{~kJ} \mathrm{~g}^{-1} \mathrm{dw}^{+} 1.15\right.$ ) and spawned/recovery gonads (21.80 $\left.\mathrm{kJ} \mathrm{g}^{-1} \mathrm{dw} \pm 0.6\right)$ (Fig. 3f).

Hoplosternum littorale - ripe individuals exhibited lower $\mathrm{I}_{\mathrm{F}}$ $(0.89 \% \pm 0.18)$, differing significantly ANOVA; $\mathrm{p}<0.01)$ from spawned/recovering individuals $(3.15 \% \pm 0.40)$ (Fig. $5 a)$. In relation to the hydrologic cycle (Fig. $5 \mathrm{~d}$ ), $\mathrm{I}_{\mathrm{F}}$ was lower during rising $(0.76 \% \pm 0.26)$ and high waters $(0.016 \% \pm 0.01)$ while the highest $\mathrm{I}_{\mathrm{F}}$ values occurred during receding $(3.58 \% \pm 0.40)$ and low waters $(1.83 \% \pm 0.21)$ (ANOVA; $\mathrm{p}<0.01)$.

During gonadal development (Fig. 5 b), ripe individuals exhibited a higher $\mathrm{I}_{\mathrm{G}}(7.65 \% \pm 0.62)$, which differed significantly (ANOVA; $\mathrm{p}<0.01)$ from the other stages: immature $(0.51 \% \pm$ $0.06)$, maturing $(2.01 \% \pm 0.53)$ and spawned/recovering $(0.61 \%$ $\pm 0.05)$. $\mathrm{I}_{\mathrm{G}}$ was higher (ANOVA; $\mathrm{p}<0.01$ ) during rising $(8.95 \% \pm$ $0.74)$ and high waters $(4.86 \% \pm 1.6)$ than during receding $(0.47 \%$ $\pm 0.02)$ and low waters $(2.03 \% \pm 0.30)$ (Fig. $4 \mathrm{e})$. 

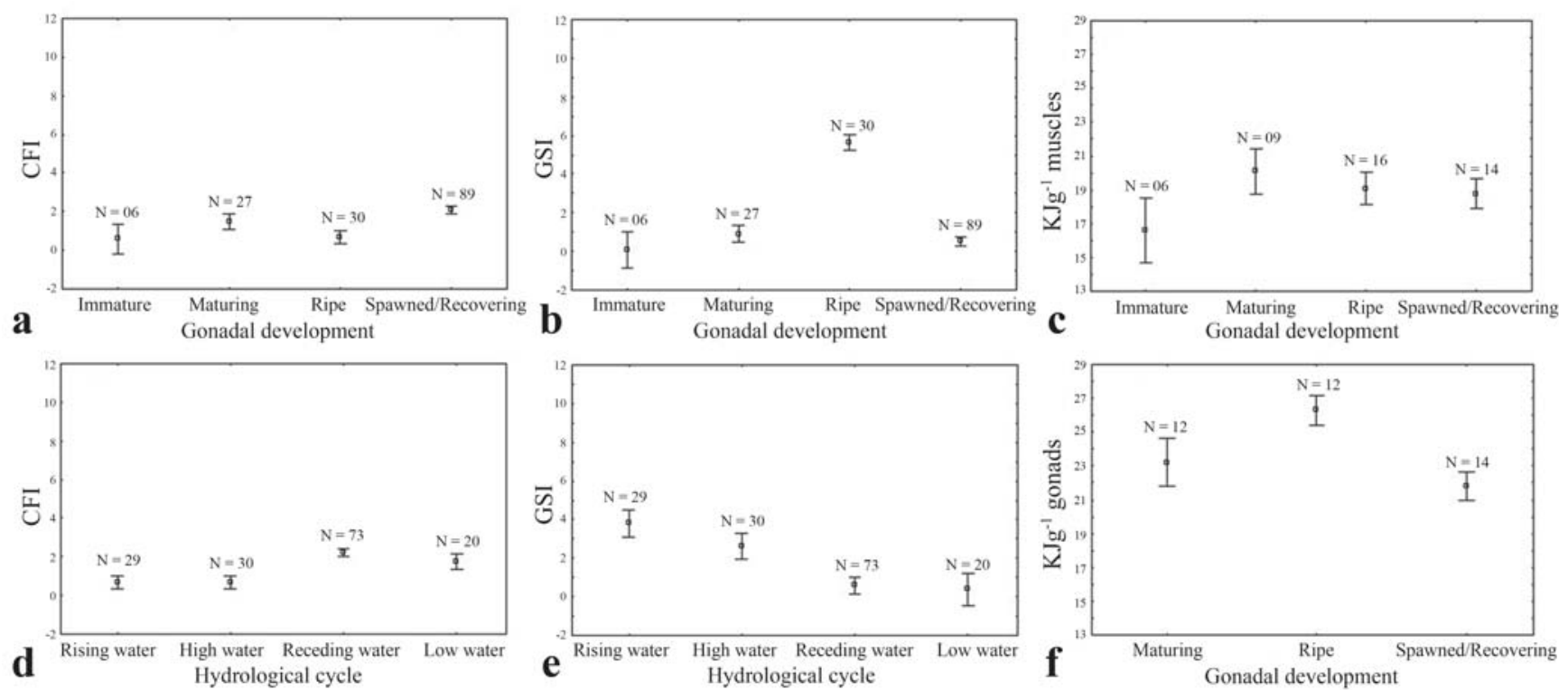

Fig. 3. Variation of CFI - cavity fat index (a), GSI - gonadosomatic index (b), muscle energy (c) and gonadal energy (f), by gonadal development; CFI (d) and GSI (e) by hydrological cycle (July/2004 - June/2005) of Acestrorhynchus falcirostris.

For this species, the greatest number of ripe individuals was sampled during rising waters (Fig. 4c). The energy content of muscles of ripe individuals $\left(20.05 \mathrm{~kJ} \mathrm{~g}^{-1} \mathrm{dw} \pm 0.56\right)$, was significantly lower (ANOVA; $\mathrm{p}<0.01$ ) when compared with the muscles of maturing $\left(21.21 \mathrm{~kJ} \mathrm{~g}^{-1} \mathrm{dw} \pm 0.51\right)$ and spawned/ recovering individuals $\left(21.20 \mathrm{~kJ} \mathrm{~g}^{-1} \mathrm{dw} \pm 0.98\right)$ (Fig. 5c). The analyses of the energy content of the gonads during the reproductive cycle (Fig. 5f), showed lowest amounts of energy in spawned/recovering $\left(20,54 \mathrm{~kJ} \mathrm{~g}^{-1} \mathrm{dw} \pm 0.32\right)$ and maturing individuals (21.18 kJ g-1 dw \pm 1.3$)$, and highest in ripe individuals (25.07 $\left.\mathrm{kJ} \mathrm{g}^{-1} \mathrm{dw} \pm 1.6\right)$ (ANOVA; $\mathrm{p}<0.01$ ).

Pygocentrus nattereri - $\mathrm{I}_{\mathrm{F}}$ was highest in individuals with ripe gonads $(1.63 \% \pm 0.29)$ (Fig. 6a). For individuals with immature $(0.46 \% \pm 0.11)$, maturing $(0.30 \% \pm 0.16)$ and spawned/recovering gonads $(0.34 \% \pm 0.12)$, mean $\mathrm{I}_{\mathrm{F}}$ was significantly lower (ANOVA; $\mathrm{p}<0.01$ ). In relation to the hydrologic cycle (Fig. 6d), the highest values of $\mathrm{I}_{\mathrm{F}}$ occurred during rising $(1.32 \% \pm 0.38)$ and receding waters $(0.96 \% \pm 0.25)$, whilst the lowest value of this index occurred during high water period $(0.21 \% \pm 0.04)$, (ANOVA; $p<0.01)$. $\mathrm{I}_{\mathrm{G}}$ was lowest in individuals with immature $(0.23 \% \pm 0.06)$, maturing $(0.79 \%$ $\pm 0.28)$ and spawned/recovering gonads $(0.61 \% \pm 0.03)$, differing significantly (ANOVA; $\mathrm{p}<0.01$ ) from those with ripe gonads $(4.37 \% \pm 0.50)$ (Fig. $6 \mathrm{~b})$. Considering the hydrologic cycle (Fig. 6e), the lowest mean $I_{G}$ values occurred during high $(0.16 \% \pm 0.15)$ and receding waters $(0.53 \pm 0.26)$, and the highest mean values occurred during rising waters $(4.28 \% \pm 0.39)$ (ANOVA; $\mathrm{p}<0.01$ ). The greatest number of individuals with ripe gonads was captured during rising waters, while the majority of fish with maturing and immature gonads were captured during high and receding waters respectively (Fig. 4b).

Significant differences between the values of muscle
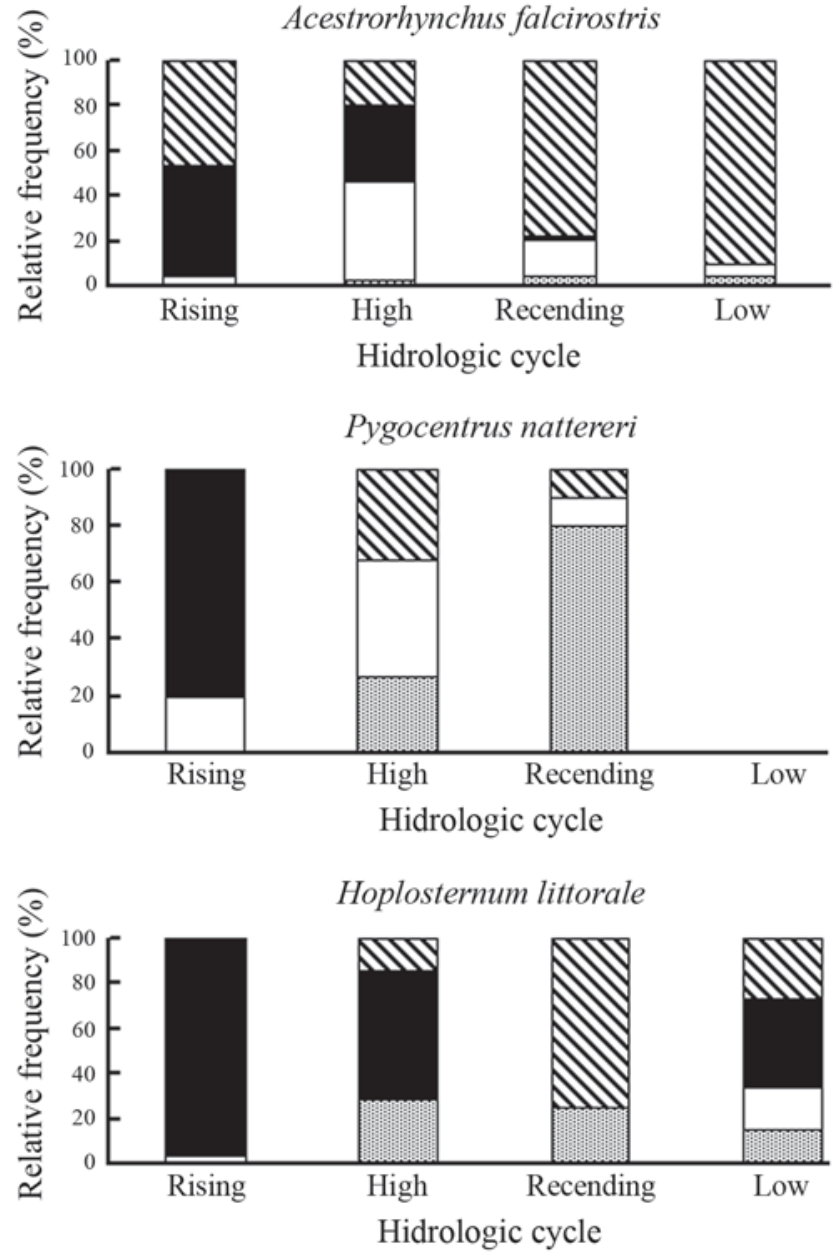

mimmature aMaturing $\square$ Mature $\mathbf{\Delta S p a w n e d / R e c o v e r i n g}$

Fig. 4. Relative frequency of gonadal phases by hydrological periods for the three species. 

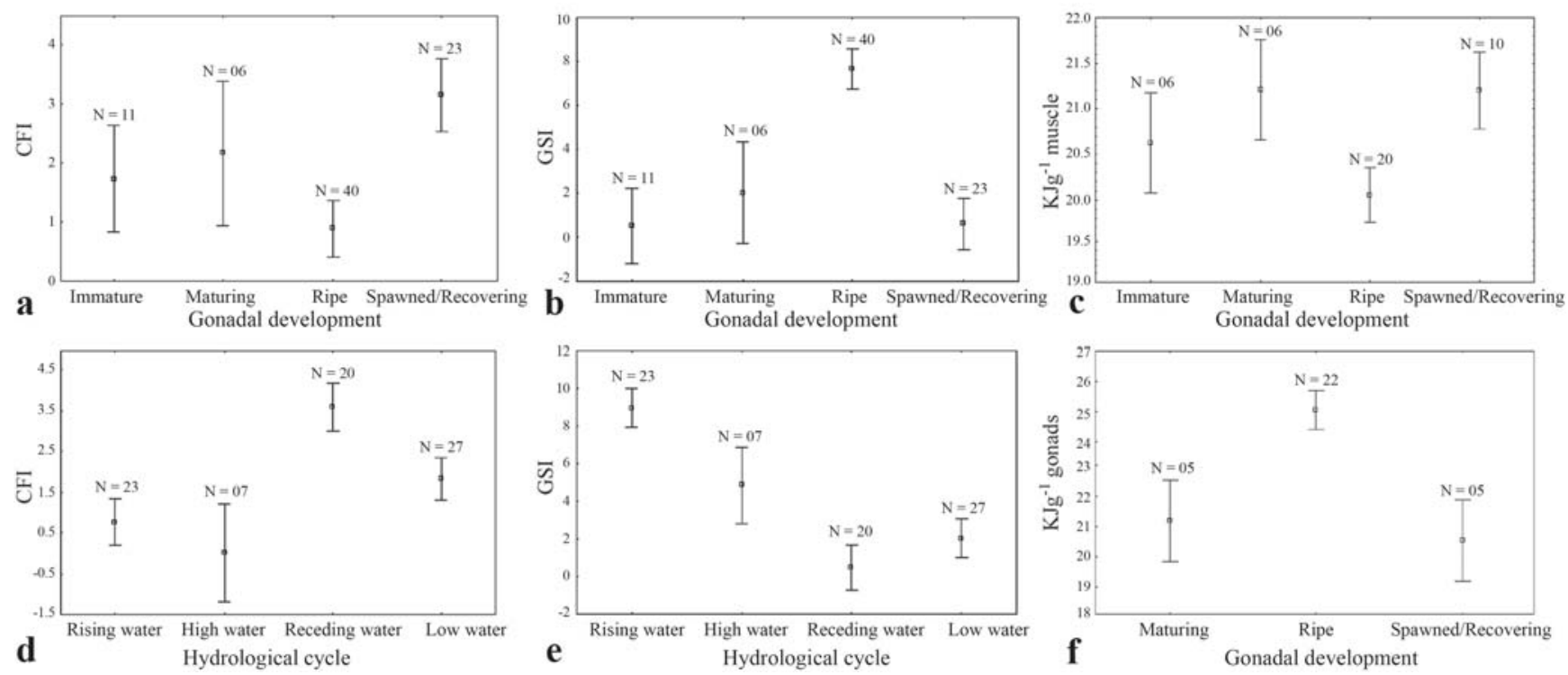

Fig. 5. Variation of CFI - cavity fat index (a), GSI - gonadosomatic index (b), muscle energy (c) and gonadal energy (f), by gonadal development; CFI (d) and GSI (e) by hydrological cycle (July/2004 - June/2005) of Hoplosternum littorale.
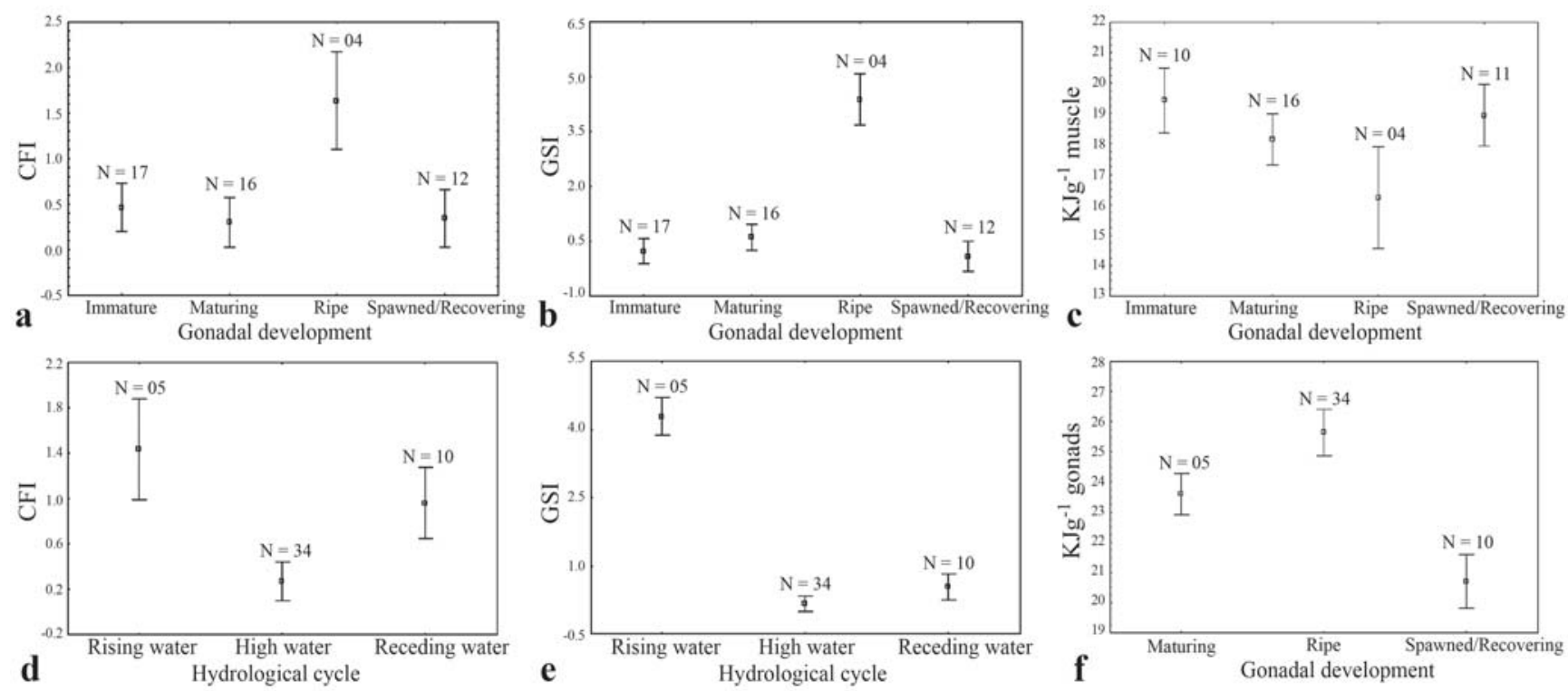

Fig. 6. Variation of CFI - cavity fat index (a), GSI - gonadosomatic index (b), muscle energy (c) and gonadal energy (f), by gonadal development; CFI (d) and GSI (e) by hydrological cycle (July/2004 - June/2005) of Pygocentrus nattereri.

energy content were observed throughout the reproductive cycle. Individuals with maturing and ripe gonads exhibited lower amounts of energy in their muscles $\left(18.1 \mathrm{~kJ} \mathrm{~g}^{-1} \mathrm{dw} \pm 2.2\right.$ and $16.2 \mathrm{~kJ} \mathrm{~g}^{-1} \mathrm{dw} \pm 0.3$ respectively) than those with immature and spawned/recovering gonads $\left(19.4 \mathrm{~kJ} \mathrm{~g}^{-1} \mathrm{dw} \pm 0.6\right.$ and $18.9 \mathrm{~kJ} \mathrm{~g}^{-1} \mathrm{dw} \pm 1.5$ respectively), (ANOVA; $\mathrm{p}<0.01$ ) (Fig. 6c). Mean values for energy content of gonads throughout reproductive cycle (Fig. 6f), were highest in the ripe stage $\left(25.6 \mathrm{~kJ} \mathrm{~g} \mathrm{~g}^{-1} \mathrm{dw} \pm 1.0\right)$ and lower in those with maturing $(23.6 \mathrm{~kJ}$ $\left.\mathrm{g}^{-1} \mathrm{dw} \pm 0.50\right)$ and spawned/recovering gonads $\left(20.7 \mathrm{~kJ} \mathrm{~g}^{-1} \mathrm{dw}\right.$ \pm 0.17 ), (ANOVA; $\mathrm{p}<0.01$ ).

\section{Discussion}

Most reproductive activity of the three species occurred during rising waters. The highest energy content in the gonads, the highest frequency of ripe females and the highest gonadosomatic indices were observed during the same period. Other studies on the reproductive biology of Amazonian fish species have identified rising and high waters as the periods of the year during which the majority of species reproduce (Fernandes \& Merona, 1988; Vazzoler \& Amadio, 1990; Isaac et al., 2000). 
The energy acquired by fish through feeding is used for reproduction, metabolism, and growth, or is accumulated in the form of energy reserves (Jobling, 1994). In general, immature individuals exhibited lower concentrations of muscular energy and body cavity fat. In juveniles, most of the energy is allocated to metabolism and somatic production, leaving low levels of energy in their bodies (Tytler \& Calow, 1985). Conversely, adults store large amounts of energy to support reproductive processes (Wootton, 1985). For $A$. falcirostris, significant differences in energy content of gonads among maturing, ripe and spawned/recovering individuals were observed, whereas the energy content of their muscles were not significantly different. These results suggest that this species does not use energy stored in muscle during gonadal development, that is, there is a direct flow of energy from its body cavity fat reserves to the gonads. Similarly, Dória \& Andrian (1997), investigating the patterns of variation in energy content of somatic (muscle and liver) and reproductive (gonads) tissues of Schizodon borellii (Boulenger, 1900) and Pimelodus maculatus (La Cèpede, 1803) of the Paraná River floodplain, showed that the highest energy content of gonads with oocytes already in the process of vitellogenesis, did not promote reduction of the somatic reserves, suggesting that in this phase of the reproductive process, visceral fat acts as the energy source necessary to support gonadal development.

The lowest indices of muscular energy observed in ripe females of $H$. littorale in the period of greatest reproductive activity (rising waters), indicate that, beyond reserves of body cavity fat, it can also utilize energy accumulated in the muscles to support the reproductive process. Encina \& Granado-Lorencio (1997), studying the seasonal variation in the energy content of Leuciscus pyrenaicus (Günther, 1868), registered a decline in the amount of energy in somatic tissues, as a result of an increase in reproductive tissues, which, according to the authors, demonstrates a transfer of energy reserves from the somatic tissues to the gonads. Previous research relates that muscles represent an important energy store for some fish species (Eliassen \& Vahl, 1982; van Dijk et al., 2005).

Acestrorhynchus falcirostris and Hoplosternum littorale showed a gradual increase in gonadosomatic index correlated with a decrease in the index of body cavity fat. This inverse relationship between $I_{G}$ and $I_{F}$ observed for these species demonstrates the allocation of energy accumulated in the form of fat for gonadal development, which requires energy for oocyte maturation. According to Zwolinski et al. (2001), significant amounts of body cavity fat are used by fish to supply the high energy cost required for gonadal development.

Pygocentrus nattereri showed the lowest energy values in muscles of individuals with ripe gonads, suggesting a mobilization of muscular energy for gonadal development. For this species, a different means of using body cavity fat was observed as its highest cavity fat indices were registered during the period of reproduction, suggesting that body cavity fat is not used for the gonadal maturation processes.

Moreover, $P$. nattereri had a lower gonadosomatic index than either $A$. falcirostris or $H$. littorale. According to Junk (1985), species that have relatively low $\mathrm{I}_{\mathrm{G}}$ produce smaller numbers of oocytes and due to environmental factors such as food availability, species with this type of life history, including Cichla ocellari (Bloch \& Schneider, 1801), Plagioscion squamosissimus (Heckel, 1840), and Astronotus ocellatus (Agassiz, 1831), do not have variable body lipid quantities throughout reproductive process.

Fish recruitment does not depend upon energetic resources allocated to reproductive process only, but also on the synchrony between reproductive timing and site. The remarkable flood pulse regime present in the Amazon region determine biological conditions in the life cycle of fishes such as reproductive activity and energy allocation patterns.

\section{Acknowledgements}

This work was supported by the CNPq and the Instituto Nacional de Pesquisas da Amazônia (INPA). We are grateful to Evanilde Benedito-Cecílio (UEM - NUPELIA) and Maria Inês Oliveira-Pereira (INPA) for their help in laboratory analysis.

\section{Literature Cited}

Bennemann, S. T., M. L. Orsi \& O. A. Shibatta. 1996. Atividade alimentar de espécies de peixe do rio Tabagi, relacionada com o desenvolvimento de gordura e das gônadas. Revista Brasileira de Zoologia, 13(2): 501-512.

Bittencourt, M. M. \& S. A. Amadio. 2007. Proposta para identificação rápida dos períodos hidrológicos em áreas de várzea do Rio Solimões - Amazonas nas proximidades de Manaus. Acta Amazônica, 37(2): 303-308.

Carvalho, F. M. 1979. Estudo da alimentação, desenvolvimento dos ovários e composição química de Hypophthalmus edentatus (Spix, 1829) e Potamorhina pristigaster (Steindachner, 1978) do lago do Castanho, AM, Brasil. Unpublished MSc. Dissertation, Instituto Nacional de Pesquisas da Amazônia, Universidade Federal do Amazonas, Manaus, 102p.

Chellappa, S., A. Huntingford, R. H. C. Strangs \& R. Y. Thomson. 1995. Condition factor and hepatosomatic index as estimates of energy status in male three-spined stickleback. Journal of Fish Biology, 47(5): 775-787.

van Dijk, P. L. M., I. Hardewig \& F. Hölker. 2005. Energy reserves during food deprivation and compensatory growth in juvenile roach: the importance of season and temperature. Journal of Fish Biology, 66: 167-181.

Dória, C. R. \& I. F. Andrian. 1997. Variation in energy content of somatic and reproductive tissues related to the reproductive cycle and feeding of female Pimelodus maculatus Lacépède, 1803 (Siluriformes, Pimelodidae) and Schizodon borellii Boulenger, 1985 (Characiformes, Anastomidae). Revista UNIMAR, 19(2): 421-437.

Dourado, E. C. S. \& E. Benedito-Cecílio. 2005. Ecologia energética de peixes: influência de fatores bióticos e abióticos. Coleção Fundamentum, 16: 07-53. 
Eggleton, M. A. \& H. L. Schramm, Jr. 2004. Feeding ecology and energetic relationships with habitat of blue catfish, Ictalurus furcatus, and flathead catfish, Pylodictis olivaris, in the lower Mississippi River, U.S.A. Environmental Biology of Fishes, 70(2): 107-121.

Eliassen, J. E. \& O. Vahl. 1982. Seasonal variations in biochemical composition and energy content of liver, gonad and muscle of native and immature cod, Gadus morhua (L.) from Balsfjorden, northern Norway. Journal of Fish Biology, 20: 707-716.

Encina L. \& C. Granado-Lorencio. 1997. Seasonal changes in condition, nutrition, gonad maturation an energy content in barbel, Barbus sclateri, inhabiting a fluctuating river. Environmental Biology of Fishes, 50(1): 75-84.

Fernandes, C. C. \& B. Merona. 1988. Lateral migrations of fish on a floodplain system in the Central Amazon (Careiro Island Lake Rei), Br. Preliminary Analysis. Memoria de La Sociedad de Ciencias Naturales La Salle, 48(2): 409-432.

Ferreira, E. J. G., J. A. S. Zuanon \& G. M. Santos. 1998. Peixes comerciais do médio Amazonas, Região de Santarém - PA. Brasília, Ibama, 211p.

Finstad, A. G., O. K. Berg \& A. Lohrmann. 2003. Seasonal variation in body composition of Arctic char, Salvelinus alpinus, from an ultraoligotrophic alpine lake. Ecology of Freshwater Fish, 12: 228-235.

Fiorin, R., A. Malavasi, A. Franco \& P. Franzoi. 2007. Comparative energy allocation in two sympatric, closely related gobies: the black goby Gobius niger and the grass goby Zosterisessor ophiocephalus. Journal of Fish Biology, 70(2): 483-496.

Goulding, M., R. Barthem \& E. Ferreira. 2003. The Smithsonian: atlas of the Amazon. Hong Kong, Smithsonian, 253p.

Hoffmayer, E. R., G. R. Parsons \& J. Horton. 2006. Seasonal and interannual variation in the energetic condition of adult male Atlantic sharpnose shark Rhizoprionodon terraenovae in the northern Gulf of Mexico. Journal of Fish Biology, 68(2): 645-653.

Huntingford, F. A., S. Chellappa, A. C. Taylor \& R. H. Strang. 2001. Energy reserves and reproductive investment in male threespined sticklebacks, Gasterosteus aculeatus. Ecology of Freshwater Fish, 10: 111-117.

Isaac, V. J., V. L. C. Rocha \& S. Q. C. Mota. 2000. Ciclo reprodutivo de algumas espécies de peixes comerciais do baixo Amazonas. Pp. 31-61. In: Recursos pesqueiros do Médio Amazonas - Biologia e Estatística Pesqueira. Série Estudo Pesca, Coleção Meio Ambiente. Brasília, Ibama, 86p.

Jégu, M. 2003. Subfamily Serrasalminae. Pp. 182-196. In: Reis, R. E., S. O. Kullander \& C. J. Ferraris, Jr. (Eds.). Check List of the Freshwater Fishes of South and Central America. Porto Alegre, Edipucrs, 729p.

Jobling, M. 1994. Fish Bioenergetics. New York, Chapman and Hall, 294p.

Jonsson, B. \& N. Jonsson. 2005. Lipid energy reserves influence lifehistory decision of Atlantic salmon (Salmo salar) and brown trout (S. trutta) in fresh water. Ecology of Freshwater Fish, 14: 296-301.

Jucá-Chagas, R. \& L. Boccardo. 2006. The air-breathing cycle of Hoplosternum littorale (Hancock, 1828) (Siluriformes: Callichthyidae). Neotropical Ichthyology, 4(3): 371-373.

Junk, W. J. 1985. Temporary fat storage, an adaptation of some fish species to the river level fluctuations and related environmental changes of the Amazon river. Amazoniana, 9: 315-351.

Junk, W. J., P. B. Bayley \& R. E. Sparks. 1989. The flood pulse concept in river flood-plain systems. Pp. 110-127. In: Dodge, D. P. (Ed.). Proceedings of the International Large River Symposium. Canadian Special Publications on Fish Aquatic Science, 106.
Mazzoni, R. \& R. Iglesias-Rios. 2002. Environmentally related life history variations in Geophagus brasiliensis. Journal of Fish Biology, 61: 1606-1618.

Menezes, N. A. 2003. Family Acestrorhynchidae. Pp. 231-233. In: Reis, R. E., S. O. Kullander \& C. J. Ferraris, Jr. (Eds.). Check List of the Freshwater Fishes of South and Central America. Porto Alegre, Edipucrs, 729p.

Penczak, T., A. A. Agostinho, N. S. Hahn \& L. C. Gomes. 1999. Energy budgets of fish populations in two tributaries of the Paraná River, Paraná, Brazil. Journal of Tropical Ecology, 15: 159-177.

Reis, R. E., S. O. Kullander \& C. J. Ferraris, Jr. 2003. Check List of the Freshwater Fishes of South and Central America. Porto Alegre, Edipucrs, 729p.

Santos, R. N., C. C. Andrade, A. F. G. N. Santos, L. N. Santos \& F. G. Araújo. 2005. Hystological analysis of ovarian development of the Characiform Oligosarcus hepsetus (Cuvier, 1829) in a Brazilian reservoir. Brazilian Journal of Biology, 65(1): 169177.

Santos, R. N., E. J. G. Ferreira \& S. A. Amadio. 2008. Effect of seasonality and trophic group on energy acquisition in Amazonian fish specie. Ecology of Freshwater Fish, 17: 340348.

Tytler, P. \& P. Calow. 1985. Fish Energetics: new perspectives. Sydney, Croom Helm, 349p.

Val, A. L. \& V. M. Almeida-Val. 1999. Biology of Tropical Fishes. Manaus, INPA, 460p.

Vazzoler, A. E. A. M. 1996. Biologia e reprodução de peixes teleósteos: teoria e prática. Maringá, Eduem, 169p.

Vazzoler, A. A. M. \& S. A. Amadio. 1990. Aspectos biológicos de peixes Amazônicos. XIII. Estrutura e comportamento de cardumes multiespecíficos de Semaprochilodus (Characiformes, Prochilodontidae) no baixo rio Negro, Amazonas, Brasil. Revista Brasileira de Biologia, 50(3): 537-546.

Wootton, R. J. 1985. Energetics of reproduction. Pp. 231-254. In: Tytler, P. \& P. Calow (Eds.). Fish Energetics: new perspectives. Sydney, Croom Helm, 410p.

Zar, J. H. 1999. Biostatistical Analysis. New Jersey, Prentice Hall, 662p.

Zwolinski, J., Y. Stratoudakis \& E. Soares. 2001. Intra-annual variation in the batch fecundity of sardine off Portugal. Journal of Fish Biology, 58: 1633-1645.

Accepted August 2, 2009 